NASA/TM-2015-218846

\title{
Space Shuttle Rudder/Speed Brake Actuator-A Case Study. Probabilistic Fatigue Life and Reliability Analysis
}

Fred B. Oswald

Glenn Research Center, Cleveland, Ohio

Michael Savage

University of Akron, Akron, Ohio

Erwin V. Zaretsky

Glenn Research Center, Cleveland, Ohio 


\section{NASA STI Program . . . in Profile}

Since its founding, NASA has been dedicated to the advancement of aeronautics and space science. The NASA Scientific and Technical Information (STI) Program plays a key part in helping NASA maintain this important role.

The NASA STI Program operates under the auspices of the Agency Chief Information Officer. It collects, organizes, provides for archiving, and disseminates NASA's STI. The NASA STI Program provides access to the NASA Technical Report Server-Registered (NTRS Reg) and NASA Technical Report ServerPublic (NTRS) thus providing one of the largest collections of aeronautical and space science STI in the world. Results are published in both non-NASA channels and by NASA in the NASA STI Report Series, which includes the following report types:

- TECHNICAL PUBLICATION. Reports of completed research or a major significant phase of research that present the results of NASA programs and include extensive data or theoretical analysis. Includes compilations of significant scientific and technical data and information deemed to be of continuing reference value. NASA counter-part of peer-reviewed formal professional papers, but has less stringent limitations on manuscript length and extent of graphic presentations.

- TECHNICAL MEMORANDUM. Scientific and technical findings that are preliminary or of specialized interest, e.g., "quick-release" reports, working papers, and bibliographies that contain minimal annotation. Does not contain extensive analysis.
- CONTRACTOR REPORT. Scientific and technical findings by NASA-sponsored contractors and grantees.

- CONFERENCE PUBLICATION. Collected papers from scientific and technical conferences, symposia, seminars, or other meetings sponsored or co-sponsored by NASA.

- SPECIAL PUBLICATION. Scientific, technical, or historical information from NASA programs, projects, and missions, often concerned with subjects having substantial public interest.

- TECHNICAL TRANSLATION. Englishlanguage translations of foreign scientific and technical material pertinent to NASA's mission.

For more information about the NASA STI program, see the following:

- Access the NASA STI program home page at http://www.sti.nasa.gov

- E-mail your question to help@sti.nasa.gov

- Fax your question to the NASA STI Information Desk at 757-864-6500

- Telephone the NASA STI Information Desk at 757-864-9658

- Write to:

NASA STI Program

Mail Stop 148

NASA Langley Research Center Hampton, VA 23681-2199 
NASA/TM-2015-218846

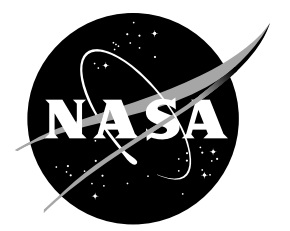

\section{Space Shuttle Rudder/Speed Brake Actuator-A Case Study. Probabilistic Fatigue Life and Reliability Analysis}

Fred B. Oswald

Glenn Research Center, Cleveland, Ohio

Michael Savage

University of Akron, Akron, Ohio

Erwin V. Zaretsky

Glenn Research Center, Cleveland, Ohio

Prepared for the

2012 Annual Meeting and Exhibition

sponsored by the Society of Tribologists and Lubrication Engineers

St. Louis, Missouri, May 6-10, 2012

National Aeronautics and

Space Administration

Glenn Research Center

Cleveland, Ohio 44135 
Trade names and trademarks are used in this report for identification only. Their usage does not constitute an official endorsement, either expressed or implied, by the National Aeronautics and Space Administration.

This work was sponsored by the Fundamental Aeronautics Program at the NASA Glenn Research Center.

Level of Review: This material has been technically reviewed by technical management.

Available from

NASA STI Program

Mail Stop 148

NASA Langley Research Center

Hampton, VA 23681-2199
National Technical Information Service 5285 Port Royal Road Springfield, VA 22161 703-605-6000

This report is available in electronic form at http://www.sti.nasa.gov/ and http://ntrs.nasa.gov/ 


\title{
Space Shuttle Rudder/Speed Brake Actuator-A Case Study. Probabilistic Fatigue Life and Reliability Analysis
}

\author{
Fred B. Oswald* \\ National Aeronautics and Space Administration \\ Glenn Research Center \\ Cleveland, Ohio 44135 \\ Michael Savage \\ University of Akron \\ Akron, Ohio 44325 \\ Erwin V. Zaretsky ${ }^{\dagger}$ \\ National Aeronautics and Space Administration \\ Glenn Research Center \\ Cleveland, Ohio 44135
}

\begin{abstract}
The U.S. Space Shuttle fleet was originally intended to have a life of 100 flights for each vehicle, lasting over a 10-year period, with minimal scheduled maintenance or inspection. The first space shuttle flight was that of the Space Shuttle Columbia (OV-102), launched April 12, 1981. The disaster that destroyed Columbia occurred on its 28th flight, February 1, 2003, nearly 22 years after its first launch. In order to minimize risk of losing another Space Shuttle, a probabilistic life and reliability analysis was conducted for the Space Shuttle rudder/speed brake actuators to determine the number of flights the actuators could sustain. A life and reliability assessment of the actuator gears was performed in two stages: a contact stress fatigue model and a gear tooth bending fatigue model. For the contact stress analysis, the Lundberg-Palmgren bearing life theory was expanded to include gear-surface pitting for the actuator as a system. The mission spectrum of the Space Shuttle rudder/speed brake actuator was combined into equivalent effective hinge moment loads including an actuator input preload for the contact stress fatigue and tooth bending fatigue models. Gear system reliabilities are reported for both models and their combination. Reliability of the actuator bearings was analyzed separately, based on data provided by the actuator manufacturer. As a result of the analysis, the reliability of one half of a single actuator was calculated to be 98.6 percent for 12 flights. Accordingly, each actuator was subsequently limited to 12 flights before removal from service in the Space Shuttle.
\end{abstract}

\section{Introduction}

The U.S. Space Shuttle fleet was originally intended to have a life of 100 flights for each vehicle, lasting over a 10-year period, with minimal scheduled maintenance or inspection. The first space shuttle flight was that of the Space Shuttle Columbia (OV-102), launched April 12, 1981. The disaster that destroyed Columbia occurred on its 28 th flight, February 1, 2003, nearly 22 years after its first launch.

The Space Shuttle actuators are lubricated with space-qualified National Lubricating Grease Institute grade 2 perfluoropolyalkyl ether (PFPAE) grease and were intended to operate for life without periodic re-lubrication and maintenance (Refs. 1 and 2). Many of these actuators were operated without maintenance in excess of 20 years.

\footnotetext{
${ }^{*}$ Retired.

${ }^{\dagger}$ Distinguished Research Associate.
} 
During Space Shuttle actuator inspection and refurbishment after the Columbia Space Shuttle disaster, there were external signs of corrosion on one of the Space Shuttle Rudder/Speed Brake (RSB) Actuators. Visible inspection of two partially disassembled RSB actuators from the Space Shuttle Discovery was made on September 16, 2003. Pitted gears and discolored grease were observed inside. The grease-lubricated ball bearings and gears making up the actuators exhibited various degrees of wear. In some cases the wear was severe. Both the bearings and gears operated under a dithering (rotation reversal) motion when these systems were powered during ground operations (Ref. 2).

The observations summarized above led to several research efforts to determine the causes of the grease degradation, damage and wear to estimate the future life and reliability of the shuttle actuators and to investigate design improvements for future heavily-loaded space mechanisms. These works included Morales, et al. (Ref. 1), which analyzed the condition of the grease in two actuators after 39 flights, Oswald, et al. (Ref. 2), which describes a probabilistic analysis of the life and reliability of Body Flap Actuator (BSA) bearings, Krantz, et al. (Ref. 3) and Krantz and Handschuh (Refs. 4), which examined wear of spur gears lubricated by PFPAE grease, Proctor, et al. (Ref. 5), which describes experiments to characterize gear scuffing damage observed on one gear of the power drive unit that operates the Rudder/Speed Brake (RSB) Actuators, and Handschuh, and Krantz (Ref. 6), which investigated a concern that a tooth might break off from a planet gear, potentially jamming the mechanism.

In order to minimize the risk of losing another Space Shuttle, Oswald, et al. (Ref. 2) performed experiments on a test rig under simulated conditions to determine the life and failure mechanism of the grease lubricated Space Shuttle Body Flap Actuator (BSA) bearings that support the input shaft of the space shuttle body flap actuators. The failure mechanism was wear that can cause loss of bearing preload. These experimental life data were analyzed using the 2-parameter Weibull-Johnson method (Refs. 7 and 8 ) on experimental life test data from bearings. These tests established life and reliability data for both shuttle flight and ground operation. Test data were used to estimate the failure rate and reliability as a function of the number of shuttle missions flown. The Weibull analysis of the test data for the four actuators on one shuttle, each with a 2-bearing shaft assembly, established a reliability level of 96.9 percent for a life of 12 missions. A probabilistic system analysis for four shuttles, each of which has four actuators, predicts a single bearing failure in one actuator of one shuttle after 22 missions (a total of 88 missions for a 4-shuttle fleet). This prediction is comparable with actual shuttle flight history in which a single actuator bearing was found to have failed by wear at 20 missions.

The work of Oswald, et al. (Ref. 2) was extended to perform a probabilistic life and reliability analysis of the Space Shuttle Rudder/Speed Brake (RSB) Actuators to determine the number of flights and/or the probability of failure that the actuators could sustain based on rolling-element (contact) fatigue of the rolling-element bearings and gears and tooth bending fatigue for a minimum of 12 Space Shuttle missions. (The 12 mission life requirement was based on the test data for the Space Shuttle Body Flap Actuator (BSA) bearings discussed above.) Accordingly, the objectives of the work reported were to (1) determine the life and reliability of each of the gears and bearings in a Rudder/Speed Brake (RSB) Actuator and (2) extend the analysis to the four RSB actuators on each shuttle vehicle to estimate the system reliability.

\section{Nomenclature}

$\begin{array}{ll}a & \text { major semiaxis of contact ellipse, } \mathrm{m} \text { (in.) } \\ a_{1} & \text { life adjustment factor for reliability } \\ a_{2} & \text { life adjustment factor for materials and processing } \\ a_{3} & \text { life adjustment factor for operating conditions including lubrication } \\ B & \text { gear material constant, } \mathrm{N} / \mathrm{m}^{1.979}\left(\mathrm{lbf} / \mathrm{in} .^{1.979}\right) \\ C_{D} & \text { basic dynamic capacity of a ball or roller bearing, } \mathrm{N}(\mathrm{lbf}) \\ C_{t} & \text { basic dynamic capacity of gear tooth, } \mathrm{N}(\mathrm{lbf})\end{array}$




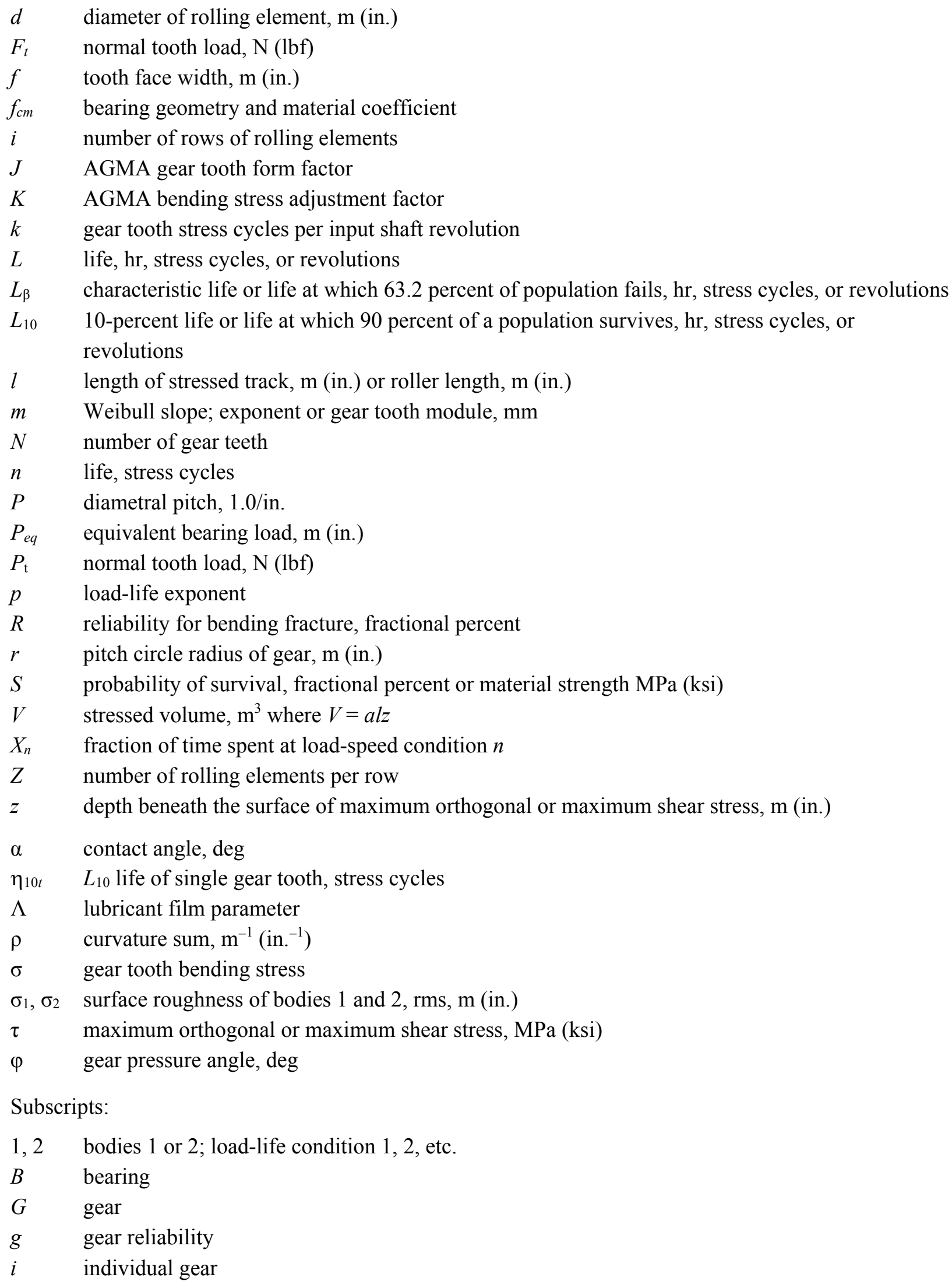




$\begin{array}{ll}n & \text { body } n \text { or load-life condition } n \\ \text { ref } & \text { reference } \\ s, \text { sys } & \text { system } \\ t & \text { tooth }\end{array}$

\section{Rudder/Speed Brake (RSB) Actuator System}

The Space Shuttle Rudder/Speed Brake (RSB) Actuator system is contained in the Space Shuttle Orbiter tail section shown in Figure 1. The actuator system comprises a power drive unit and four actuators. Each actuator contains two complete gear trains, designated left and right. The system controls the RSB panels through the four actuators that are driven by a single power drive unit.

A schematic of an RSB actuator is shown in Figure 2. The actuators are designed to provide both rudder and speed brake functions by a split design in the vertical tail section shown in Figure 1 in which two input shafts enter the actuator. By rotating the shafts in the same direction, the panels are moved concurrently for the rudder function. When the input shafts rotate in opposite directions, the panels move apart for the speed brake function. Both functions can be used simultaneously.

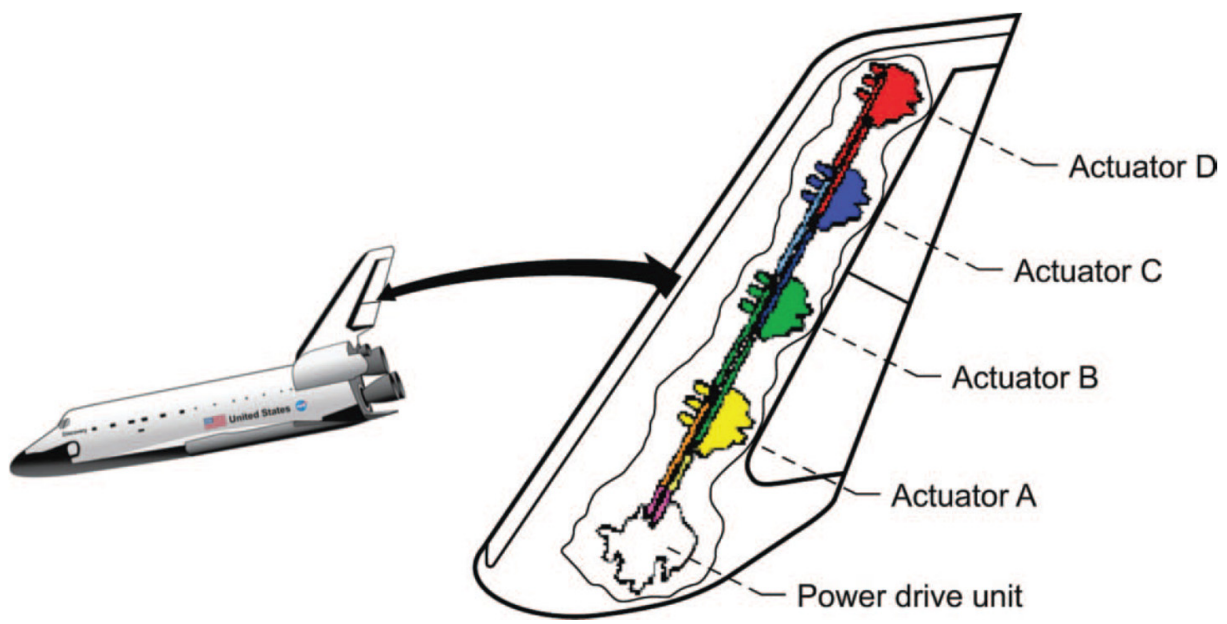

Figure 1.-Rudder/speed brake actuating components.

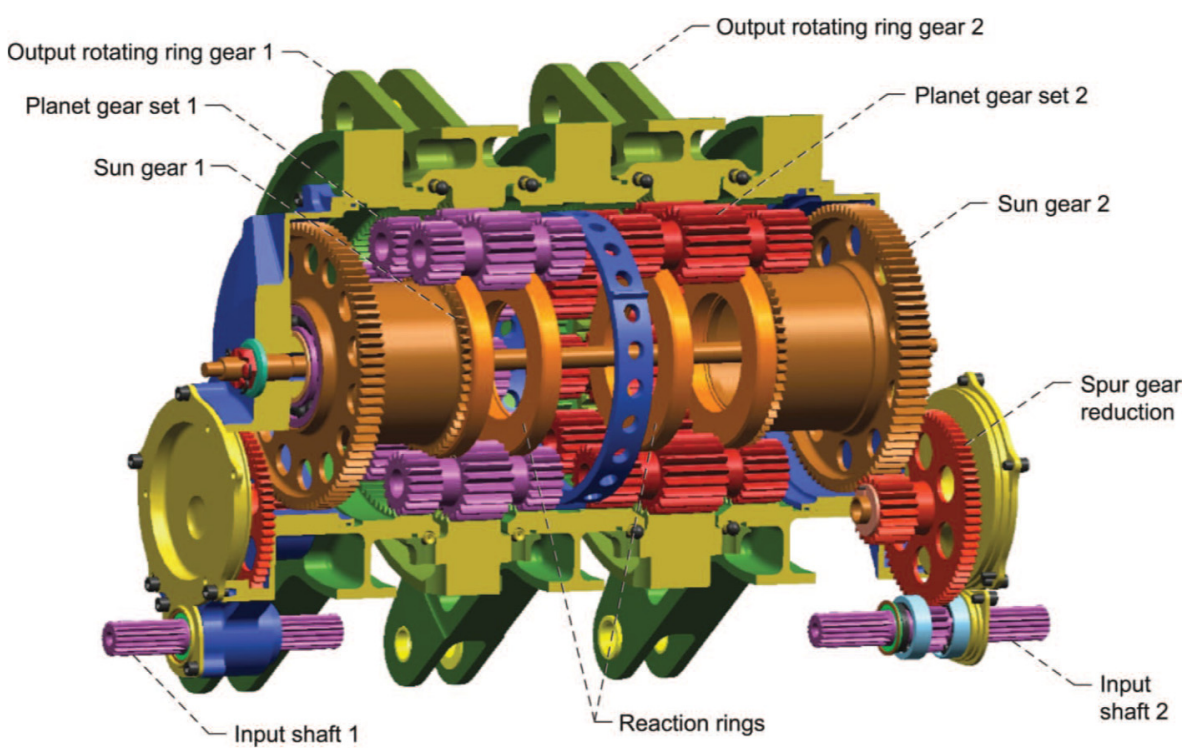

Figure 2.-Schematic of space shuttle rudder/speed brake (RSB) actuator. 
The 1L (left) rudder/speed brake gearbox shown in Figure 2 (designated Actuator A in Fig. 1) is composed of a 19.75:1 offset compound spur reduction followed by a differential planetary with a 24:1 speed ratio. The overall speed ratio is 474:1. The input shafts are shown in the lower right and left corners of the figure. A series of two spur reductions bring the input power to the shaft of a sun gear, which drives a nine-planet differential planetary with two ring gears, one of which is fixed. In this arrangement, the fixed ring gear is split into two parts that straddle the output ring gear. The sun gear has a small face width and drives the rightmost planet set that meshes with the fixed ring gear. It is placed near the center of the planet spools. The geometric properties of the gears in both the compound spur reduction and the differential planetary reduction are given in Table 1.

In Table 1, the gear face widths were reduced to estimate the gear tooth contact stresses more closely since the analyses only deals with a constant stress across the gear face. In the planetary, the actual diametral pitch and pressure angles of the gears differ from the nominal values because the gears operate at non-standard center distances.

The compound spur gear input stage has an offset configuration with a $155^{\circ}$ angle between the two gear center-lines connecting its three shafts. The input shaft is supported by two symmetrically-placed cylindrical roller bearings. The intermediate shaft is supported by a quill of four; one-half inch wide rows of 0.125 -in. diameter rollers. This quill is modeled as two half-inch long roller bearings at its ends with increased capacity. The sun gear shaft is supported by a single ball bearing in the plane of the spur output gear. An axial thrust bearing is placed between the sun gear and the nearest of the two planet support rings.

The two support rings carry the radial loads applied to the nine planets by the fixed and output ring gears. Finally, there are two ball bearings placed between the output ring and the housing. These bearings carry the radial load associated with the hinge moment of the output arm. They also carry the axial preload applied to the rudder speed brake actuator by a rod through its center.

The gears comprising the actuators were manufactured from case carburized AISI 9310 steel. Most of the rolling-element bearing rings were manufactured from AISI 9310 steel. Two bearing rings were made from through-hardened AISI 52100 steel. The rolling elements were made from AISI 52100 steel except the balls for the bearings that connect the fixed and movable ring gears were made from AMS 6491 steel.

TABLE 1.-GEAR GEOMETRIC PROPERTIES IN COMPOUND SPUR REDUCTION AND DIFFERENTIAL PLANETARY REDUCTION

\begin{tabular}{|c|c|c|c|c|c|c|}
\hline Gear & $\begin{array}{l}\text { No. of } \\
\text { teeth }\end{array}$ & $\begin{array}{c}\text { Face width, } \\
\text { mm (in.) }\end{array}$ & $\begin{array}{c}\text { Nominal tooth } \\
\text { size, }{ }^{\text {a }} \\
\text { module-mm } \\
\text { dia. pitch }(1.0 / \text { in. })\end{array}$ & $\begin{array}{c}\text { Nominal } \\
\text { pressure angle, } \\
\text { deg. }\end{array}$ & $\begin{array}{l}\text { Working Tooth } \\
\text { size }^{\mathrm{a}} \\
\text { Module-mm } \\
\text { dia. pitch } \\
\text { (1.0/in.) }\end{array}$ & $\begin{array}{c}\text { Working } \\
\text { Pressure } \\
\text { angle, } \\
\text { deg. }\end{array}$ \\
\hline Input (1) & 16 & $10.85(0.427)$ & $\begin{array}{l}1.814 \\
(14)\end{array}$ & 25 & $\begin{array}{l}1.814 \\
(14)\end{array}$ & 25.0 \\
\hline Intermediate (2) & 69 & $10.85(0.427)$ & $\begin{array}{c}1.814 \\
(14)\end{array}$ & 25 & $\begin{array}{c}1.814 \\
(14)\end{array}$ & 25.0 \\
\hline Intermediate (3) & 19 & $23.75(0935)$ & $\begin{array}{c}2.117 \\
(12)\end{array}$ & 25 & $\begin{array}{c}2.117 \\
(12)\end{array}$ & 25.0 \\
\hline Spur Output (4) & 87 & $23.75(0935)$ & $\begin{array}{c}2.117 \\
(12)\end{array}$ & 25 & $\begin{array}{c}2.117 \\
(12)\end{array}$ & 25.0 \\
\hline Sun (5) & 54 & $3.18(0.125)$ & $\begin{array}{c}2.117 \\
(12) \\
\end{array}$ & 25 & $\begin{array}{c}2.169 \\
(11.708) \\
\end{array}$ & 27.839 \\
\hline Planet on Sun (6a) & 18 & $3.18(0.125)$ & $\begin{array}{c}2.117 \\
(12)\end{array}$ & 25 & $\begin{array}{c}2.169 \\
(11.708)\end{array}$ & 27.839 \\
\hline Planet on fixed ring (6b) & 18 & $52.20(2.055)$ & $\begin{array}{c}2.117 \\
(12)\end{array}$ & 25 & $\begin{array}{c}2.169 \\
(11.708)\end{array}$ & 27.839 \\
\hline Fixed ring (7) & 90 & $52.20(2.055)$ & $\begin{array}{c}2.117 \\
(12)\end{array}$ & 25 & $\begin{array}{c}2.169 \\
(11.708)\end{array}$ & 27.839 \\
\hline Output planet (8) & 18 & $37.34(1.470)$ & $\begin{array}{l}2.54 \\
(10)\end{array}$ & 25 & $\begin{array}{c}2.479 \\
(10.245)\end{array}$ & 21.797 \\
\hline Output ring (9) & 81 & $37.34(1.470)$ & $\begin{array}{l}2.54 \\
(10)\end{array}$ & 25 & $\begin{array}{c}2.479 \\
(10.245)\end{array}$ & 21.797 \\
\hline
\end{tabular}

${ }^{a}$ The tooth size standards in metric and in English units are different. The metric module is the pitch diameter divided by the number of teeth. The English Diametral Pitch is the number of teeth divided by the pitch diameter. 
TABLE 2.-SUMMARY OF ROLLING-ELEMENT BEARING LIVES FOR

RUDDER SPEED BRAKE ACTUATOR

\begin{tabular}{|l|c|c|c|c|c|c|c|c|}
\hline Bearing no. & $1 \mathrm{a}$ & $1 \mathrm{~b}$ & 2 & $3 \mathrm{a}$ & $3 \mathrm{~b}$ & 4 & $6 \mathrm{a}$ & $6 \mathrm{~b}$ \\
\hline Bearing type & Roller & Roller & Roller & Roller & Roller & Ball & Ball & Ball \\
\hline$L_{10}$ life (hr) & 647,000 & 647,000 & 15,823 & 4,875 & 4,875 & 54,973 & 1,509 & 1,089 \\
\hline$L_{0.1}$ life (hr) & 9,747 & 9,747 & 238 & 73 & 73 & 828 & 23 & 16 \\
\hline Min life (hr) & 34,291 & 34,291 & 839 & 258 & 258 & 2,914 & 80 & 58 \\
\hline
\end{tabular}

\section{Analytic Procedure}

For the contact stress analysis, the Lundberg-Palmgren bearing life theory (Ref. 9) was expanded to include gear-surface pitting for the actuator as a system. The mission spectrum of the Space Shuttle rudder/speed brake actuator was combined into equivalent effective hinge moment loads including an actuator input preload for the contact stress fatigue and tooth bending fatigue models.

The reliabilities from the contact stress and tooth bending analyses were calculated for a series of estimated loads and load cycles for 100 missions of the shuttle. The loads considered were the output hinge moments on the gearbox. The analyses were performed for the applied loads and for a combination of the applied loads with a-pre-load due to assembly of $50 \mathrm{lb}$-in. Once the reliabilities of the separate analyses were obtained for each loading condition, they were combined to determine an overall reliability for the gearbox for the analyzed loading conditions and cycle counts. This analysis was performed for the left half of the first actuator, with the assumption that the life and reliability of the right half were identical. The life and reliability for the four actuators on each Space Shuttle was assumed equal as well. The results were extended to the system of four full actuators on a single shuttle.

The life and reliability assessment of the gears was performed in two stages: a contact stress fatigue model and a gear tooth bending fatigue model. The actuator manufacturer provided $L_{10}$ life data for the actuator bearings, assuming a Weibull slope of 1.11. These bearing life data are shown in Table 2. The analyses do not consider the probable reduction in life and reliability caused by boundary lubrication, wear and grease degradation.

The original intent of the Space Shuttle design was for a life of 100 flights with minimal maintenance. During the Return to Flight program, post 2003 Columbia disaster, this goal was initially reduced to 20 flights. The reliability analysis for the gear tooth bending, gear tooth surface fatigue and bearing fatigue were calculated separately along with the total system reliability for 1, 12, 20, and 100 Space Shuttle flights. The reliability values did not consider other modes of failure, such as wear or lubricant degradation.

\section{Enabling Equations and Analysis}

\section{TLIFE: Transmission Life and Reliability Modeling}

The method of probabilistic design was applied to the Space Shuttle Rudder Speed Brake (RSB) left half actuator gearbox number 1L (designated Actuator A in Fig. 1). A fatigue life and reliability assessment of the gearbox was performed in two stages: a contact stress fatigue life and reliability model and a gear tooth bending fatigue life and reliability model. The initial effort to determine the fatigue life and reliability of the $1 \mathrm{~L}$ rudder speed brake actuator gearbox was focused on adapting the program TLIFE (Ref. 10) to analyze this gearbox. This program performs life and reliability analysis in three stages:

1. It determines the loads and load cycles on the components of the gearbox based on the overall load and speed of the gearbox,

2. It then determines the lives and reliabilities of the individual components based on these loads and load cycles, and

3. It combines these lives and reliabilities to determine the life and reliability of the gearbox system. 
This program did not initially include an analysis for the differential planetary described above. It did have an analysis for the compound spur gear reduction that precedes the differential planetary. The analysis for the differential planetary based on the analysis of the preceding section was added as part of this effort.

The loading for this analysis was obtained from two Shuttle Program Office tables. The first three columns of Table 3 are a list of shuttle events, the corresponding rudder speed brake applied moment and its duration in minutes. For a flight of $7.604 \mathrm{hr}, 7.25 \mathrm{hr}$ are for the ferry from the landing site to the launch site. In the original table, specific moments and times are given but no load cycle counts.

The second table, Table 4 lists load ranges for given cycle counts. The total cycle count in this table is $35,297,798$. However, 91,500 of these cycles are for reversed loading (negative moments) at lower moment ranges. These loads are applied to the opposite sides of the teeth and do not add to the positive moment fatigue damage. Removing these cycles from the total gives 35,188,298 positive load cycles for this analysis. Multiplying this total by the percent times of duration gives the estimates of the cycles for each applied moment which are presented in the last column of Table 3. These loads and cycles are the basis of this analysis. The loading condition analyzed represents a median load for the conditions considered. It should be noted that a 57,827 N (13,000 lb) axial pre-load is included in the loading on the output ring support ball bearings.

The two-parameter Weibull distribution function was used to model the statistical variations in life and strength for both models. For the contact stress analysis, the Lundberg-Palmgren bearing life theory (Ref. 9) has been expanded to include gear-surface pitting and the gearbox as a system (Ref. 11). The mission spectrum of the Space Shuttle rudder speed brake unit 1L gearbox has been combined into a single equivalent hinge moment effective load based on the contact stress fatigue model using the Linear Damage Rule also referred to as the Palmgren-Langer-Miner Rule (Refs. 12 to 13). This load was also used for the bending fatigue analysis.

TABLE 3.-EVENT DURATION

\begin{tabular}{|l|l|c|r|}
\hline Event & \multicolumn{1}{|c|}{$\begin{array}{c}\text { Moment, } \\
(\mathrm{N}-\mathrm{m}) \text { lb-in. }\end{array}$} & $\begin{array}{c}\text { Duration, } \\
\text { min }\end{array}$ & $\begin{array}{c}\text { Cycles } \\
\text { calculated }\end{array}$ \\
\hline Ferry & $(1,693) 15,000$ & 420 & $32,392,514$ \\
Ferry & $(23,953) 212,000$ & 0.25 & 19,281 \\
\hline Ascent & $(9,039) 80,000$ & 0.2 & 15,425 \\
Ascent & $(5,197) 46,000$ & 1.7 & 131,113 \\
Ascent & $(11,073) 98,000$ & 0.1 & 7,713 \\
\hline Descent & $(15,818) 140,000$ & 33 & $2,545,126$ \\
Descent & $(27,116) 240,000$ & 1 & 77,125 \\
\hline
\end{tabular}

TABLE 4.-INITIAL APPLIED LOADING INFORMATION

\begin{tabular}{|c|c|r|}
\hline \multicolumn{2}{|c|}{ Load range, N-m (in.-lb) } & \multicolumn{1}{|c|}{ Cycles } \\
\hline$-50,814$ to $-39,545$ & $(-450,000$ to $-350,000)$ & 0 \\
\hline$-39,545$ to $-28,246$ & $(-350,000$ to $-250,000)$ & 2,939 \\
\hline$-28,246$ to $-16,948$ & $(-250,000$ to $-150,000)$ & 88,561 \\
\hline$-16,948$ to $-5,649$ & $(-150,000$ to $-50,000)$ & 20,768 \\
\hline$-5,649$ to 5,649 & $(-50,000$ to 50,000$)$ & $34,369,892$ \\
\hline 5,649 to 11,298 & $(50,000$ to 100,000$)$ & 67,044 \\
\hline 11,298 to 16,948 & $(100,000$ to 150,000$)$ & 0 \\
\hline 16,948 to 22,597 & $(150,000$ to 200,000$)$ & 439,135 \\
\hline 22,597 to 28,246 & $(200,000$ to 250,000$)$ & 291,459 \\
\hline 28,246 to 33,895 & $(250,000$ to 300,000$)$ & 0 \\
\hline 33,895 to 39,545 & $(300,000$ to 350,000$)$ & 0 \\
\hline 39,545 to 45,194 & $(350,000$ to 400,000$)$ & \\
\hline$>45,194$ & $(\quad>400,000)$ & $35,297,798$ \\
\hline
\end{tabular}




\section{Weibull Analysis}

In 1939, Weibull (Refs. 16 and 17) developed a method and equation for statistically evaluating the fracture strength of materials. He also applied the method and equation to fatigue data based upon small sample (population) sizes, where

$$
\ln \ln \left(\frac{1}{S}\right)=m \ln \left(\frac{L-L_{\mu}}{L_{\beta}-L_{\mu}}\right) \quad \text { where } 0<L<\infty ; 0<S<1
$$

The location parameter $L_{\mu}$ is the time or life at or below which no failures are expected to occur or the will be 100 percent probability of survival. Equation (1a) is referred to as the three parameter Weibull equation relating life and probability of survival. If $L_{\mu}=0$, the expression is referred to as the twoparameter Weibull equation and is written as follows:

$$
\ln \ln \left(\frac{1}{S}\right)=m \ln \left(\frac{L}{L_{\beta}}\right) \quad \text { where } 0<L<\infty ; 0<S<1
$$

When plotting the $\ln \ln [1 / S]$ as the ordinate against the $\ln L$ as the abscissa, fatigue data are assumed to plot as a straight line (Fig. 3). The ordinate $\ln \ln [1 / S]$ is graduated in statistical percent of components failed or removed for cause as a function of $\ln L$, the $\log$ of the time or cycles to failure. The tangent of the line is designated the Weibull slope $m$, which is indicative of the shape of the cumulative distribution or the amount of scatter of the data (Refs. 7 and 15).

The method of using the Weibull distribution function for data analysis to determine component life and reliability was later developed and refined by Johnson (Ref. 17).

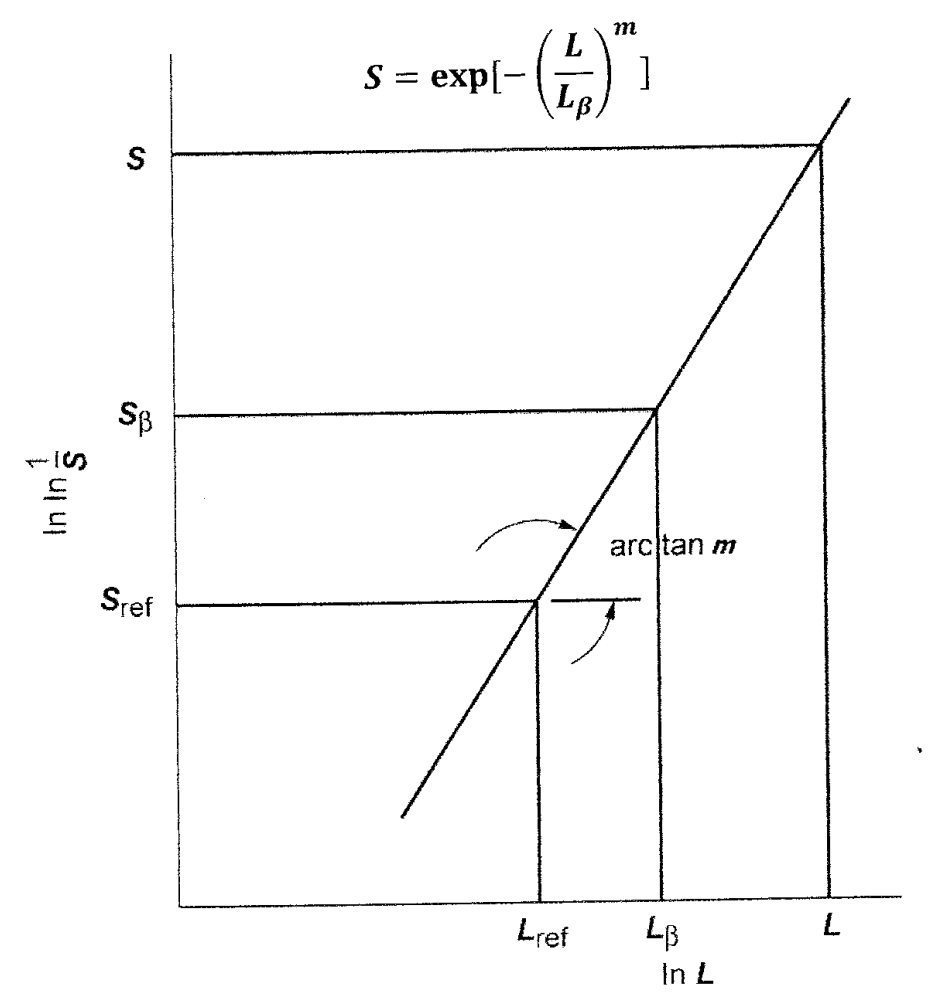

Figure 3.-Weibull plot where (Weibull) Slope of tangent or line is $m$. Probability of survival $S_{\beta}$ of 36.8 percent at which $L=L_{\beta}$ or $L / L_{\beta}=1$. 


\section{Rolling-Element Bearing Life Analysis}

Lundberg and Palmgren (Refs. 9 and 18) extended the theoretical work of Weibull (Refs. 16 and17) and showed that the probability of survival $S$ could be expressed as a power function of maximum orthogonal shear stress $\tau$, life $n$, depth of maximum orthogonal shear stress $z$, and stressed volume $V$ :

$$
\begin{aligned}
& \ln \frac{1}{S} \sim \frac{\tau^{c} n^{m}}{z^{h}} V \\
& \ln \frac{1}{S} \sim \frac{\tau^{c} n^{m} a l}{z^{h-1}}
\end{aligned}
$$

By substituting the bearing geometry and the Hertzian contact stresses for a given load into Equation (3), the bearing basic dynamic load capacity $C_{D}$ can be calculated (Ref. 9). The basic dynamic load capacity $C_{D}$ is defined as the load that a bearing can carry for a life of one-million inner-race revolutions with a 90-percent probability of survival ( $L_{10}$ life). Lundberg and Palmgren (Ref. 9) obtained the following additional relation:

$$
L_{10}=\left(\frac{C_{D}}{P_{e q}}\right)^{p}
$$

where $P_{e q}$ is the equivalent bearing load and $p$ is the load-life exponent (Ref. 9).

Formulas for the basic dynamic load ratings derived by Lundberg and Palmgren (Refs. 9 and 18) and incorporated in the ANSI/ABMA and ISO standards (Refs. 19 to 21) are as follows:

Radial ball bearings with $d \leq 25.4 \mathrm{~mm}$ :

$$
C_{D}=f_{c m}(i \cos \alpha)^{0.7} Z^{2 / 3} d^{1.8}
$$

Radial ball bearings with $d>25.4 \mathrm{~mm}$ :

$$
C_{D}=3.647 f_{c m}(i \cos \alpha)^{0.7} Z^{2 / 3} d^{1.4}
$$

Radial roller bearings:

$$
C_{D}=f_{c m}(i \ell \cos \alpha)^{7 / 9} Z^{3 / 4} d^{29 / 27}
$$

Equation (4) can be modified using life factors based on reliability $a_{1}$, materials and processing $a_{2}$, and operating conditions such as lubrication $a_{3}$ (Refs. 22 and 23) where

$$
L=a_{1} a_{2} a_{3} L_{10}
$$

For the boundary lubrication under which the rolling-element bearings in the actuator operate, the lubricant film parameter, $\Lambda$ can be used as an indicator of rolling-element bearing performance and life. For $\Lambda<1$, surface smearing or deformation, accompanied by wear will occur on the rolling surfaces and the factor $a_{3}$ in Equation (8) can vary from 0.2 to 0.5 (Ref. 22). If the effect of boundary lubrication had not been considered by the actuator manufacturer, the bearing lives summarized in Table 2 would be as much as 80 percent less than those shown. 


\section{Gear Life Analysis}

Between 1975 and 1981, Coy, Townsend, and Zaretsky (Refs. 24 to 26) published a series of papers developing a methodology for calculating the life of spur and helical gears based upon the LundbergPalmgren theory and methodology for rolling-element bearings. Coy, Townsend, and Zaretsky (Ref. 27) reported that for AISI 9310 spur gears, the Weibull slope $m_{G}$ is 2.5. Based on Equation (2), for all gears except a planet gear, the gear life can be written as

$$
L_{10_{G}}=\frac{N^{-1 / m_{G}} \eta_{10_{t}}}{k}
$$

For a planet gear, the life is

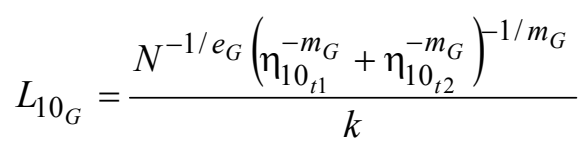

The $L_{10}$ life of a single gear tooth can be written as

$$
\eta_{10_{t}}=a_{2} a_{3}\left(\frac{C_{t}}{F_{t}}\right)^{p_{G}}
$$

where

$$
C_{t}=B f^{0.907} \rho^{-1.165} l^{-0.093}
$$

and

$$
\rho=\left(\frac{1}{r_{1}}+\frac{1}{r_{2}}\right) \frac{1}{\sin \varphi}
$$

and $\eta_{10_{t}}$ is the $L_{10}$ life in millions of stress cycles for one particular gear tooth. This number can be determined by using Equation (11), where $C_{t}$ is the basic load capacity of the gear tooth; $F_{t}$ is the normal tooth load; $p_{G}$ is the load-life exponent (usually taken as 4.3 for gears based on experimental data for AISI 9310 steel); and $a_{2}$ and $a_{3}$ are life adjustment factors similar to that for rolling-element bearings. Life factors $a_{2}$ for materials and processing are determined experimentally. The value for $C_{t}$ can be determined by using Equation (12), where $B$ is a material constant that is based on experimental data and is approximately equal to $1.39 \times 10^{8}$ when calculating $C_{t}$ in SI units (Newtons and meters) and 21800 in English units (pounds and inches) for AISI 9310 steel spur gears; $f$ is the tooth width; and $\rho$ is the curvature sum at the start of single-tooth contact.

The $L_{10_{G}}$ life of the gear (all teeth) in millions of output shaft load cycles at which 90 percent will survive can be determined from Equations (9) or (10) where $N$ is the total number of teeth on the gear; $m_{G}$ is the Weibull slope for the gear and was taken to be 2.5 (Ref. 28); and $k$ is the number of load (stress) cycles on a gear tooth per output shaft load cycle. 
TABLE 5.-RUDDER SPEED BRAKE ACTUATOR PROBABILITY OF SURVIVAL

\begin{tabular}{|c|c|c|c|c|c|c|}
\hline \multirow{2}{*}{$\begin{array}{l}\text { Number } \\
\text { of flights }\end{array}$} & \multirow{2}{*}{$\begin{array}{c}\text { Number of } \\
\text { actuators }\end{array}$} & \multicolumn{3}{|c|}{ Gear reliability, percent } & \multirow{2}{*}{$\begin{array}{c}\text { Actuator } \\
\text { bearing } \\
\text { reliability, } \\
\text { percent }\end{array}$} & \multirow{2}{*}{$\begin{array}{c}\text { Total system } \\
\text { reliability, } \\
\text { percent }\end{array}$} \\
\hline & & $\begin{array}{c}\text { Tooth } \\
\text { bending } \\
\text { fatigue }\end{array}$ & $\begin{array}{l}\text { Tooth } \\
\text { surface } \\
\text { fatigue }\end{array}$ & $\begin{array}{l}\text { Combined } \\
\text { bending } \\
\text { and surface }\end{array}$ & & \\
\hline 100 & $1 / 2$ & 95.943 & 99.978 & 95.922 & 85.950 & 82.4 \\
\hline 100 & 4 & 71.793 & 99.822 & 71.666 & 29.782 & 21.3 \\
\hline 20 & $1 / 2$ & 99.926 & 99.999+ & 99.926 & 97.495 & 97.4 \\
\hline 20 & 4 & 99.409 & 99.997 & 99.406 & 81.632 & 81.1 \\
\hline 12 & $1 / 2$ & 99.979 & $99.999+$ & 99.979 & 98.571 & 98.6 \\
\hline 12 & 4 & 99.835 & 99.999 & 99.834 & 89.126 & 89.0 \\
\hline
\end{tabular}

For all gears except the planet gears, each tooth will see load on only one side of its face for a given direction of input shaft rotation. However, each tooth on a planet gear will see contact on both sides of its face for a given direction of input shaft rotation. One side of its face will contact a tooth on the sun gear, and the other side of its face will contact a tooth on the ring gear. Equation (10) takes this into account, where $\eta_{10_{t 1}}$ is the $L_{10}$ life in millions of stress cycles of a planet tooth meshing with the sun gear, and $\eta_{10_{t 2}}$ is the $L_{10}$ life in millions of stress cycles of a planet tooth meshing with the ring gear.

Equations (9) to (13) are for gears in a single mesh only. For the case of collector gears such as parallel reduction, planetary gear trains and idler gears, the damage accumulates differently. As the load count will be different for these gears, the equations must be modified to account for this variable loading. In planets and idler gears each tooth is loaded on both faces in one rotation. Since the surface fatigue damage accumulates separately on the faces, the gear faces are treated as separate gears in their own mesh in this simulation. The load count factor, $\boldsymbol{l}_{\mathbf{c}}$, is used in other cases. This has units of load cycles per output load cycle.

For gears, this analysis used values for the Weibull slope, $m=2.5$, gearing load-life exponent, $p=4$ and dynamic capacity surface strength, $S_{a c}, 500 \mathrm{ksi}$. Based on a mission duration of $7.604 \mathrm{hr}$, the reliability (probability of survival) of the gears based on contact (surface) fatigue is given in Table 5 for 12,20 , and 100 shuttle flights.

\section{Gear Bending Life Analysis}

Gear tooth bending stresses are calculated using the AGMA bending stress adaptation of the Lewis bending stress calculation (Ref. 29). This adaptation included the Dolan and Broghammer stress concentration factor (Ref. 30). The maximum bending stress on each tooth is used for the life and reliability calculations. For both the pinion and the gear, this stress, $\sigma$, is the bending stress at the root of the tooth caused by the full mesh load $F_{t}$, applied at the highest point of single tooth contact on that tooth.

$$
\sigma=\frac{F_{t}}{f m J} K(M P a)=\frac{F_{t} P}{f J} K(\mathrm{ksi})
$$

The first part of the equation is the metric form, with the tooth size in Equation (14) defined by the gear tooth module, $m$. The second part of the equation is the English version with the tooth size defined by the diametral pitch, $P$. The symbol $J$ is the AGMA tooth form factor and the symbol $K$ is for the AGMA stress adjustment factors.

This stress is compared to the maximum allowable corresponding fatigue strength, $S$, in MPa (ksi) for AISI 9310 carburized gear steel (Ref. 31). Using a Goodman diagram, one can determine the corresponding alternate strength $S_{e}$, where the ultimate strength, $S_{u}$ is $1889 \mathrm{MPa}$ (274 ksi) where:

$$
\frac{1}{S}=\frac{0.5}{S_{u}}+\frac{0.5}{S_{e}}
$$


It is very unusual to have the full alternating strength available in an in-service device and since there is the presence of a corrosive environment after a period of time, this alternating strength will be de-rated to 80 percent of its full value. The reciprocal of Equation (15) including this de-rating factor gives the zero to maximum fatigue strength:

$$
\begin{gathered}
S=\frac{2}{\frac{1}{S_{u}}+\frac{1}{0.8 S_{e}}}=\frac{2}{\frac{1}{1889}+\frac{1}{752}}=1076 \mathrm{MPa} \\
S=\frac{2}{\frac{1}{S_{u}}+\frac{1}{0.8 S_{e}}}=\frac{2}{\frac{1}{274}+\frac{1}{109}}=150 \mathrm{ksi}
\end{gathered}
$$

Using Equations (14) to (16), a bending stress analysis of the gears can be performed to determine their life and reliability in terms of the maximum fatigue strength $S$, load-life factor $p$ and Weibull slope $m$.

The bending stress is directly proportional to the load. Accordingly,

$$
L \sim\left(1 / P_{t}\right)^{p} \sim(1 / S)^{p}
$$

The load-life factor can be determined from the slope of the S-N curve in the region between one-thousand cycles to failure and one-million cycles to failure. For AISI 9310 carburized gear steel, $S=1076 \mathrm{MPa}(156 \mathrm{ksi})$. Due to insufficient statistical tooth bending stress life data, a value of $m=2.5$ is estimated for the bending stress-life Weibull slope. This is the same Weibull slope as used for the gear tooth contact-stress life slope. It is higher than that used for the bearing contact stress life slope. With the 90-percent reliability fatigue strength equal to $0.9 S_{u}$ at $10^{3}$ cycles and the endurance strength equal to $S$ at $10^{6}$ cycles, the load-life factor $p$ becomes:

$$
p=\frac{\ln L_{2}-\ln L_{1}}{\ln S_{1}-\ln S_{2}}=\frac{\ln 10^{6}-\ln 10^{3}}{\ln \left(0.9 S_{u}\right)-\ln S}=\frac{\ln 10^{6}-\ln 10^{3}}{\ln (0.9(1889))-\ln (1076)}=11.6
$$

The maximum bending stress on each tooth is used for the life and reliability calculations. For both the pinion and the gear, this stress is the bending stress at the root of the tooth caused by the full mesh load at the highest point of single tooth contact on that tooth. The load-life relationship for bending fatigue is:

$$
L_{10, g}=\left(\frac{S}{\sigma}\right)^{p}
$$

where $L_{10, g}$ is the 90 -percent reliability life of the gear for the applied stress, $\sigma$. In terms of this life, the gear reliability $R_{g}$ for a given life, $L$, is given by:

$$
\ln \left(\frac{1}{R_{g}}\right)=\ln \left(\frac{1}{0.9}\right)\left(\frac{L}{L_{10, g}}\right)^{m}
$$


With the life and reliability of the gears in a single mesh established, the next step is to combine the analyses for all the meshes. For this analysis, the system bending reliability is the product of all the individual bending reliabilities:

$$
R_{s}=\prod R_{i}
$$

The pinion torque for each gear mesh is determined as a ratio to the output hinge moment on the rudder speed brake. The number of teeth in engagement in each mesh for a single output ring gear tooth engagement is counted.

The load cycles throughout the gearbox for every output ring motion of one tooth engagement, which equals $1 / 81$ of a revolution or $4.444^{\circ}$ were counted. Since there are nine planets, the fixed and movable ring gears each see nine tooth load cycles. Although each of the nine planets that mesh with the ring gears see only one load cycle, collectively they see nine. Each planet-sun mesh sees four load cycles for each planet-ring cycle (four teeth mesh at the sun for each tooth at the ring), thus the count for the sun with its planets is 36 .

The two meshes in the compound spur reduction are a little different. The spur-sun mesh sees 26 load cycles. However, the intermediate gear that meshes with this gear has only 19 teeth. Thus, seven of its teeth see two load cycles and 12 teeth see only one load cycle. The input mesh sees the most load cycles with 14 of the teeth on the input spur seeing six load cycles for the one tooth rotation of the output.

The overall reliability for all the meshes taken together is the product of all the calculated reliabilities in the analysis. By calculating this analysis with different loads for one-million cycles, the dynamic capacity of the gearbox in bending is determined. It is the load that produces a reliability of 90 percent for one-million stress cycles.

\section{System Life Prediction}

The $L_{10}$ lives of the individual bearings and gears that make up a rotating machine are calculated for each condition of their operating profiles. For each component, the resulting lives from each of the operating conditions are combined using the linear damage (Palmgren-Langer-Miner) rule (Refs. 12 to 15) where

$$
\frac{1}{L}=\frac{X_{1}}{L_{1}}+\frac{X_{2}}{L_{2}}+\cdots \frac{X_{n}}{L_{n}}
$$

The Lundberg-Palmgren bearing life theory was expanded to include gear-surface pitting for the gearbox as a system. A second fatigue life and reliability analysis was also conducted for the bending fatigue lives of the gear teeth in the actuator. Gear and bearing system reliabilities were calculated and combined using strict series reliability where

$$
S=S_{1} \cdot S_{2} \cdot S_{3} \cdot \ldots S_{n}
$$

At a specified reliability, the cumulative lives of each of the machine components are combined to determine the calculated machine system $L_{10}$ life using the Lundberg-Palmgren formula (Ref. 9):

$$
\frac{1}{L_{s y s}^{m}}=\left(\frac{1}{L_{B_{1}}^{m_{B}}}+\frac{1}{L_{B_{2}}^{m_{B}}}+\cdots \frac{1}{L_{B_{n}}^{m_{B}}}\right)+\left(\frac{1}{L_{G_{1}}^{m_{G}}}+\frac{1}{L_{G_{2}}^{m_{G}}}+\cdots \frac{1}{L_{G_{n}}^{m_{G}}}\right)
$$


Unfortunately, Equation (23) is only an approximation since the system Weibull slope varies with load. In a balanced life transmission, the system Weibull slope will be somewhere between the highest and the lowest of the components' Weibull slopes. A form of this equation can be solved numerically for system reliability as a function of life and plotted on Weibull coordinates (Ref. 32). The resulting graph can be fitted with a straight line to determine the system Weibull slope and the system $L_{10}$ life. In the event of an unbalanced life transmission, the lowest lived component will dominate the transmission failures and thus can serve as a good approximation for the system Weibull properties. However, at a given reliability, the system life will always be lower than the lowest lived component because other components can also fail.

Based upon the Lundberg-Palmgren equation, the $L_{10}$ life for the actuator as a system can be calculated where:

$$
L_{10}=\left[\frac{C}{T}\right]^{p}
$$

$C$ is the theoretical load that produces a life of one million cycles (designated the dynamic capacity), $T$ is the equivalent output torque and $p$ is the load-life exponent. Using the Linear Damage Rule, where $X_{n}$ is the time and $T_{n}$ is the torque at condition $n$ :

$$
T=\frac{X_{1} T_{1}^{p}+X_{2} T_{2}^{p}+X_{3} T_{3}^{p}+\ldots+X_{n} T_{n}^{p}}{X_{1}+X_{2}+X_{3}+\ldots+X_{n}}
$$

A mission spectrum for the actuator as supplied by the NASA Shuttle Program Office was used to compute effective hinge moment loads for both gear tooth contact stress and tooth bending stress using the Palmgren-Langer-Miner linear damage rule.

A gear contact stress fatigue model established the output hinge moment dynamic capacity for the actuator as $44860 \mathrm{~N}-\mathrm{m}$ (397 $050 \mathrm{in}-\mathrm{lb})$ with a Weibull slope of 2.5 and load-life exponent of 3.64. A similar analysis for tooth bending fatigue produced a dynamic capacity of $25280 \mathrm{~N}-\mathrm{m}$ (223 $740 \mathrm{in}-\mathrm{lb})$ with Weibull slope of 2.5 and load-life exponent of 11.6 .

A loading spectrum for 100 missions consisting of 35188292 load cycles was assumed for the gearbox. Output hinge moment loads varied from 1700 to $27100 \mathrm{~N}-\mathrm{m}$ (15 000 to $240000 \mathrm{in}-\mathrm{lb})$. An input preload of $5.6 \mathrm{Nm}$ (50 in-lb) added $2010 \mathrm{Nm}$ (17 $800 \mathrm{in}-\mathrm{lb})$ to the external hinge moment for the analysis.

\section{Results and Discussion}

\section{Rudder/Speed Brake (RSB) Actuator Loading}

The Rudder/Speed Brake Actuator was designed and manufactured in the 1970's for an expected life of 100 missions over a period of 10 years with no definitive plans for relubrication, maintenance and refurbishment. At that time and during the course of the operation of the Space Shuttle Fleet and until the time of the Columbia disaster, it was assumed by the Shuttle Program Office that no maintenance would be required of the actuators and/or that no failure should be anticipated. In other words, there would be a 100 percent probability of survival for the designated 100 missions. As a result, design loads were not available for the analysis reported by us.

The Shuttle Program Office did provided two simplified load versus time and load cycle tables shown in Tables 3 and 4. These tables give load ranges for an operation in output load cycles. It was assumed that the frequency of loading was constant for all missions and that the full cycle count of 35188298 positive load cycles was the total for the 100 missions. On this basis, the cycles were totaled, each time was converted to a percent time and this percent was multiplied by the 35188298 cycles to obtain the number of cycles at each listed load. The average mission duration operating time was given as $7.604 \mathrm{hr}$. 


\section{Rolling-Element Bearing Life}

The $L_{10}$ lives of the bearings, (the rolling-element fatigue life at a 90-percent probability of survival) were calculated by the actuator manufacture for the left half of actuator number 2 and were not recalculated by us. Based on Equation (1a), for each of the bearings, the location parameter $L_{\mu}$ is the time below which no failures would be expected (100 percent probability of survival) where $L_{\mu}=0.053 L_{10}$ (Ref. 23). These results are shown in Table 2. However, as previously discussed, the analyses reported do not consider the negative effects of grease degradation, boundary lubrication and resultant wear on the life and reliability of the bearings and gears.

The lowest lived bearing in the system dictates the time below which no bearing failure should occur. From Table 2 this time is $58 \mathrm{hr}$. Based on an average mission duration operating time of $7.604 \mathrm{hr}$ and using the two-parameter Weibull equation (Eq. (1b)), the probability of survival for each bearing was calculated for $1,12,20$, and 100 missions. The product of the reliabilities of the individual bearings represents the reliability of the system of bearings in one-half actuator.

These results are shown in Table 5 for 12, 20, and 100 shuttle flights. Based on the results reported for bearing $6 \mathrm{~b}$ (Table 2) having a life of $58 \mathrm{hr}$ below which no failure should occur, it can be reasonably concluded that the bearings as a system will operate with no failure for about 8 missions $(58 \mathrm{hr} / 7.604 \mathrm{hr}$ per mission).

\section{Gear Contact Fatigue Life}

Gear tooth failures can be similar to failures of bearing elements. However, there are a few differences due to the complex shape of the gear tooth. Most differences result in sudden tooth breakage in a poorly lubricated, overloaded mesh. For our analysis we did not consider this as a failure mode.

For the gear analysis the values for the Weibull slope, $m=2.5$, gearing load-life exponent, $p=4$ and dynamic capacity surface strength, $S_{a c}=3450 \mathrm{MPa}(500 \mathrm{ksi})$. Based on a mission duration of $7.604 \mathrm{hr}$, the reliability (probability of survival) of the gears based on contact (surface) fatigue is given in Table 5 for 12,20 , and 100 shuttle flights.

\section{Gear Bending Fatigue Life}

A bending stress analysis of the gears was performed to determine their life and reliability in terms of the maximum fatigue strength $S$, load-life factor $p$ and Weibull slope $m$ that have been determined. These values are: $S=1076 \mathrm{MPa}$ (156 ksi), $p=11.6$ and $m=2.5$, respectively.

The maximum bending stress on each tooth was used for the life and reliability calculations. For both the pinion and the gear, this stress is the bending stress at the root of the tooth caused by the full mesh load at the highest point of single tooth contact on that tooth.

The result of this analysis is a dynamic capacity of $25279 \mathrm{~N}-\mathrm{m}$ (223 $741 \mathrm{in}-\mathrm{lb})$. Coupled with the load-life factor of 11.6 and the Weibull slope of 2.5, this dynamic capacity enabled the bending stress life and reliability to be calculated along with the life and reliability for contact stress. The resulting reliabilities based on tooth bending fatigue are summarized in Table 5 for 12, 20, and 100 shuttle flights.

\section{Rudder/Speed Brake (RSB) System Reliability}

The reliabilities for the gears and bearings are summarized for a single half actuator (the 1L (left) rudder/speed brake gearbox shown in Fig. 2) and for four full actuators as a system in Table 5 for 12, 20 and 100 flights. The bearing reliabilities are summarized under the column "Actual Bearing Reliability" in Table 5. The reliability of the gears as a system is summarized under "Gear Reliability for each failure

mode in Table 5. The column showing "Combined Bending and Surface" reliability is the product of the reliabilities for "Tooth Bending Fatigue" and "Tooth Surface Fatigue." The Total System Reliability 
shown under the column "Total System Reliability" in Table 5 is the product of the reliabilities shown in each line for the "Combined Bending and Surface Reliability" for the gears and the "Actuator Bearing Reliability."

There are four full actuators on each shuttle. The failure of a single actuator can result in the loss of a shuttle. When considering the probability of survival of four actuators together these numbers become 89.0, 81.1 and 21.3 percent for 12, 20, and 100 flights, respectively. For 20 flights the probability of a gear failure in one of four actuators is less than 0.6 percent. However, for 100 flights the probability of a gear failure in any one of four actuators increases to 28.3 percent where bending fatigue failure becomes the predominant mode of gear failure. This is an unacceptable risk.

The reliability of the bearings was determined separately from those of the gears. Combining the bearing and gear statistical analysis for 8 missions results in a 100 percent probability of survival for all four actuators as a system. The reliability of the gears in the actuators for both surface and bending fatigue is higher than the reliability of the bearings. This means the reliability of this system is dominated by the reliability of its bearings.

The Weibull plots of Figure 4 illustrate this. They are for the sub-systems and full system of Rudder Speed Brake 1L. The gear surfaces sub-system, shown to the far right as a dashed line is by far the strongest with the highest reliabilities. The gear teeth bending sub-system is somewhat less reliable and weaker and dominates the gear system reliability. Finally, the bearings are the weakest system which dominates the full system reliability at high reliabilities or low percent of failures.

These life and reliability data for a single half actuator were assumed to apply to all four full rudder speed brake actuators used in the Space Shuttle. Based on four RSB actuators per shuttle, the probability of survival or the actuators as a system is the probability of survival of a single half actuator at a designated number of flights to the $8^{\text {th }}$ power or $S^{8}$. The Weibull plots of Figure 5 show the comparison of the reliabilities of the $1 \mathrm{~L}$ gearbox and the full system of four gearboxes with their higher statistical percent of failures and lower reliabilities.

The above analysis does not include wear as a failure mode. Wear, as fatigue, is probabilistic and not deterministic. We know that wear occurred in the RSB actuators. However, without an experimental data base and predefined acceptable wear criterion for critical components, wear as a failure mode could not be analytically predicted.

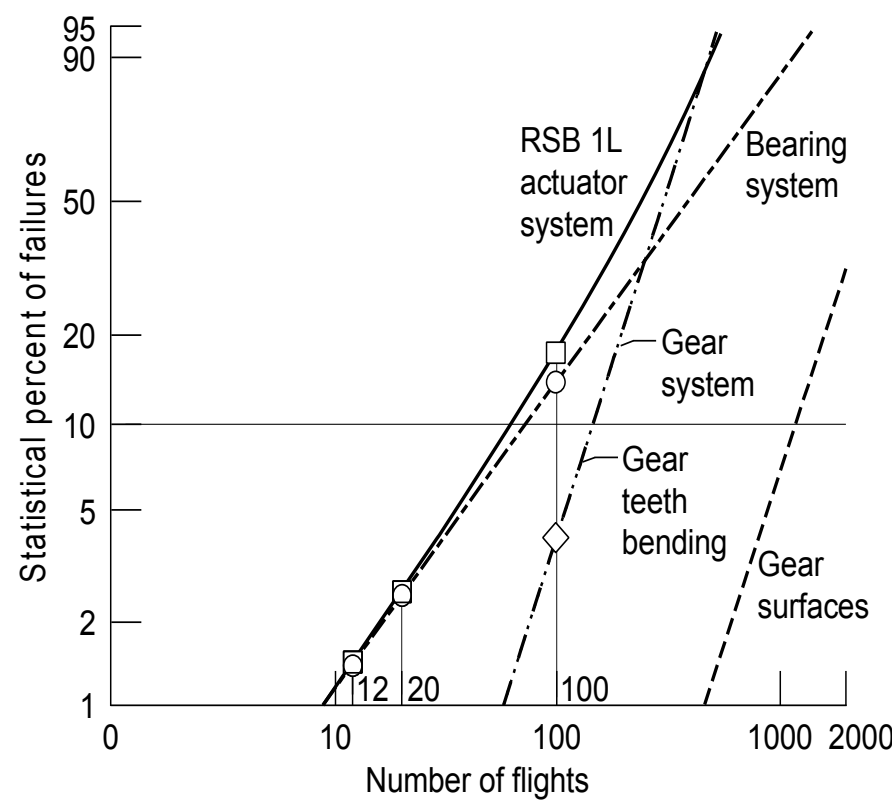

Figure 4.--Rudder speed brake $1 \mathrm{~L}$ actuator component and system Weibull plots. 


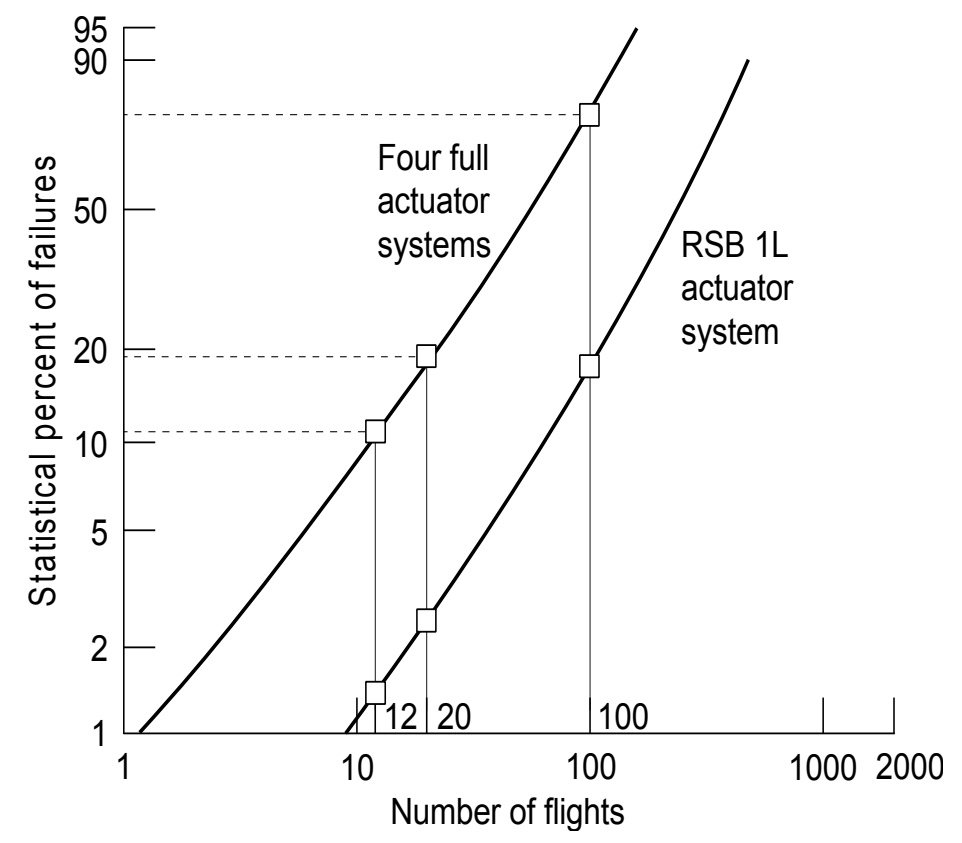

Figure 5.-System Weibull plot for $1 \mathrm{~L}$ actuator and four full actuators.

\section{General Comments}

From Table 5, the 81.1 percent system reliability for 20 flights was deemed an unacceptable risk for the Space Shuttle. As a result, the number of future flights per actuator was limited to 12 . The reliability for 12 flights on a single half actuator was calculated to be 98.6 percent. The reliability of the four full actuators as a system in a single Space Shuttle was calculated to be 89.0 percent for 12 flights. This means the probability of fatigue failure of the bearings or gears in the system of four full RSB actuators on a single shuttle is 11 percent over a life of 12 flights.

Because of time constraints, a life and reliability analysis was not performed by us on the Space Shuttle Body Flap Actuator (BSA) gears and bearings. However, Oswald, et al. (Ref. 2), performed experiments on a test rig under simulated conditions to determine the life and failure mechanism of the grease lubricated Space Shuttle Body Flap Actuator (BFA) bearings that support the input shaft of the Space Shuttle body flap actuators. The Weibull analysis of the test data for the four Space Shuttle Body Flap Actuators (BFA) on one shuttle, each with a 2-bearing shaft assembly, established a reliability level of 96.9 percent for a life of 12 missions. For the purpose of our analysis, it was assumed by us that this reliability is that for the entire BFA assembly. If this reliability is for the entire BFA assembly, then the combined reliability with the RSB assembly for 12 missions on a single Space Shuttle was 86.2 percent $[(0.969 \times 0.890) \times 100]$. This yields a 13.8 percent probability that a bearing and/or gear failure will occur on either a BFA or RSB actuator.

In the 1970's when the Space Shuttle Rudder/Speed Brake (RSB) Actuator was designed and manufactured, a sophisticated gearbox life probabilistic life and reliability analysis of the type presented in this article was not available. The Rudder/Speed Brake Actuator was designed for a life of 100 missions over a period of 10 years with no definitive plans for relubrication, maintenance and refurbishment. However, a bearing life and reliability analysis was performed by the manufacturer of the actuators. The bearing analysis performed by us and reported herein was an extension of the one performed by the manufacturer. In previous related studies (Refs. 1 to 6), are reported the effects of boundary lubrication, grease degradation and wear on body flap (BFA) and rudder speed brake (RSB) actuators' life and reliability. For this fatigue study, we did not consider the negative effects of boundary lubrication, wear and grease degradation on bearing and gear life and reliability. 
The risk of a rudder speed brake actuator bearing failure (not including the risk of gear failures) that could result in the loss of a Space Shuttle at 100 missions was 70.2 percent. For 20 missions that risk was reduced to 18.4 percent. However, it appears that the NASA Program Office did not examine or extend the bearing analysis to reflect the reliability and/or consider that an actuator bearing failure could be a probable cause for loss of a Space Shuttle. This omission was further compounded by a failure to provide for a scheduled maintenance program to remove, examine, repair, replace, and/or refurbish these actuators based on time and missions flown.

\section{Summary of Results}

A probabilistic life analysis was applied to the Space Shuttle Rudder/Speed Brake (RSB) Actuator 1L. A contact stress fatigue model and a gear tooth bending fatigue model were used for a life and reliability assessment of the gears. Life and reliability of the bearings in the actuator were analyzed separately, based on data provided by the actuator manufacturer using the Lundberg-Palmgren life model. The life and reliability results for the gears and bearings in a single half actuator were combined using strict series reliability. The life and reliability of each of the four full actuators was assumed equal and the results extended to the four actuators on each shuttle as a single system. Although the analyses do not consider the probable reduction in life and reliability caused by boundary lubrication, wear and grease degradation, the recommendation to limit actuators to 12 flights before refurbishment addresses this concern. The following results were obtained.

1. Based on the analysis, the Space Shuttle Rudder/Speed Brake Actuators were limited to 12 flights each in order to maintain a reliability of 98.6 percent for any half actuator and 89.0 percent for the system of four full actuators on one shuttle.

2. The life and reliability of the actuator gears as a system for both surface and bending fatigue is higher than the life and reliability of the bearings as a system. Thus, the life and reliability of the actuator system is dominated by that of the bearings.

3. Based on the original design requirement of the Space Shuttle, the rudder/speed brake actuator system, comprising four actuators on each shuttle, has a calculated reliability of 81.1 percent for a life of 20 flights and a reliability of 21.3 percent for a life of 100 flights.

\section{Epilog}

The body flap (BFA) actuators on all remaining space shuttles were limited to 12 flights each before refurbishment. The remaining two rudder speed brake (RSB) actuators were removed from the Space Shuttle Discovery. All four of the removed rudder speed brake (RSB) actuators were replaced with four actuators that had been subjected to three flights and had been removed from a sister space shuttle. On July 26, 2005 the Discovery returned to flight on a mission to the International Space Station (ISS), the first Space Shuttle to fly since the Space Shuttle Columbia disaster on February 1, 2003. This was the $31^{\text {st }}$ mission and flight of the Discovery. On July 4, 2006, the $32^{\text {nd }}$ flight of the Discovery occurred on a mission to the ISS. This was the second consecutive return to flight since the Columbia disaster. The Discovery was flown seven more times to the ISS without incident for a total of 39 flights. After the $39^{\text {th }}$ mission on March 9, 2011 the Space Shuttle Discovery was retired from service and was placed on permanent display in the Smithsonian Air and Space Museum, Washington, D.C. The body flap (BFA) actuators and the rudder speed brake (RSB) actuators functioned as intended without incident. The rudder speed brake (RSB) actuators in the Discovery at the time of its retirement had a total of 12 flights, 9 flights from those in the Discovery and 3 previous flights before being removed from the Space Shuttle Endeavor (Ref. 1). 


\section{References}

1. Morales, W., Street, K. W., and Zaretsky, E. V., "Performance and Analysis of Perfluorinated Grease used on Space Shuttle Actuators-A Case Study," Tribology Transactions, 55, 1, 2011, pp. 77-85.

2. Oswald, F. B., Jett, T. R., Predmore, R. E., and Zaretsky, E. V., "Probabilistic Analysis of Space Shuttle Body Flap Actuator Ball Bearings," Tribology Transactions, 51, 2, 2008, pp. 193-202.

3. Krantz, T. L., Oswald, F. B., and Handschuh, R. F., "Wear of Spur Gears Having Dithering Motion and Lubricated With a Perfluorinated Polyether Grease," ASME Paper No. DETC2007-34089, 2007.

4. Krantz, T. L., and Handschuh, R. F., "A Study of Spur Gears Lubricated With GreaseObservations from Seven Experiments," NASA/TM 2005-213957 and ARL TR-3159, 2005.

5. Proctor, M., Oswald, F. B., and Krantz, T. L., "Shuttle Rudder/Speed Brake Power Drive Unit (PDU) Gear Scuffing Tests With Flight Gears," NASA/TM—2005-214092, 2005.

6. Handschuh, R. F., and Krantz, T. L., "Engagement of Metal Debris into a Gear Mesh," NASA/TM2010-216759, 2010.

7. Johnson, L. G. The Statistical Treatment of Fatigue Experiments. Elsevier Publishing Co., Amsterdam, Netherlands, 1964.

8. Vlcek, B. L., and Zaretsky, E. V., "Rolling-Element Fatigue Testing and Data Analysis - A Tutorial," Tribology Transactions, 54 (4), 2011, pp. 523 - 541.

9. Lundberg, G., and Palmgren, A., Dynamic Capacity of Rolling Bearings, Acta Polytechnica Mechanical Engineering Series, 1, 3, Stockholm, Sweden, 1947.

10. Savage, M., Prasanna, M. G., Rubadeux, K. L., "TLIFE: A Program for Spur, Helical and Spiral Bevel Transmission Life and Reliability Modeling," NASA-CR4622 (ARL-TR-506), 1994.

11. Savage, M., Rubadeux, K. L., Coe, H. H., and Coy, J. J., "Spur, Helical and Spiral Bevel Transmission Life Modeling," AIAA Jour. of Propulsion and Power, 12, 2, pp. 283 -288, March - April 1996.

12. Palmgren, A., "The Service Life of Ball Bearings," NASA-TT-F-13460, 1971 (Transl. from Z. Ver. Devt. Ingr., vol. 68, no. 14, 1924, pp. 339-341).

13. Langer, B.F, "Fatigue Failure From Stress Cycles of Varying Amplitude," J. App. Mech., 4, (4), 1937, pp. A-160-A-162.

14. Miner, M.A., "Cumulative Damage in Fatigue," J. Appl. Mech., 12, (3), 1945, pp. A-159-A-164.

15. Zaretsky, E. V., "Rolling Bearing Life Prediction, Theory, and Application," Recent Developments in Wear, Friction and Lubrication, G. K. Nikas, ed., Research Signpost, Kerala, India, 2010, pp. 45-136.

16. Weibull, W., "A Statistical Theory of the Strength of Materials." Proceedings of the Royal Swedish Institute of Engineering Research (Ingenioersvetenskapsakad. Handl.) 151, 1939, pp. 5-55.

17. Weibull, W, "The Phenomenon of Rupture in Solids." Proceedings of the Royal Swedish Institute of Engineering Research (Ingeniorsvetenskapsakad. Handl.), 153, 1939, pp. 1-55.

18. Lundberg, G., and Palmgren, A., Dynamic Capacity of Roller Bearings, Acta Polytechnica Mechanical Engineering Series, 2, (4), Stockholm, Sweden, 1952.

19. ISO 281:1990, Rolling Bearings-Dynamic Load Ratings and Rating Life. Ed. 1, International Organization for Standardization, Geneva, Switzerland, 1990.

20. ANSI/ABMA-9, (1990), Load Ratings and Fatigue Life for Ball Bearings. Anti-Friction Bearing Manufacturers Association, Washington, DC.

21. ANSI/ABMA-11, (1990), Load Ratings and Fatigue Life for Roller Bearings: Anti-Friction Bearing Manufacturers Association, Washington, DC.

22. Zaretsky, E. V., ed., Tribology for Aerospace Applications, STLE SP-37, 1997.

23. Zaretsky, E. V., ed., (1992), STLE Life Factors for Rolling Bearings, STLE SP-34, 1992. 
24. Coy, J.J.; Townsend, D.P.; and Zaretsky, E.V., "Dynamic Capacity and Surface Fatigue Life for Spur and Helical Gears," J. Lubr. Technol. Trans. ASME, 98 (2), Series F, 1976, pp. 267-276.

25. Coy, J.J., Townsend, D. P., and Zaretsky, E. V., "Analysis of Dynamic Capacity of Low-ContactRatio Spur Gears Using Lundberg-Palmgren Theory, NASA TN D-8029, 1975.

26. Coy, J.J.; and Zaretsky, E.V., "Life Analysis of Helical Gear Sets Using Lundberg-Palmgren Theory," NASA TN D-8045, 1975.

27. Coy, J.J.; Townsend, D.P.; and Zaretsky, E.V., "An Update on the Life Analysis of Spur Gears," Advanced Power Transmission Technology, G.K. Fischer, ed., NASA CP-2210, 1983, pp. 421-434.

28. Townsend, D.P.; Coy, J.J.; and Zaretsky, E.V., "Experimental and Analytical Load-Life Relation for AISI 9310 Steel Spur Gears," J. Mech. Des., Trans. ASME, 100 (1), 1978, pp. 54-60.

29. ANSI/AGMA 2001-D04, Fundamental Rating Factors and Calculation Methods for Involute Spur and Helical Gear Teeth, American Gear Manufacturers Association, Alexandria, VA.

30. Dolan, T.J.; and Broghamer, E.L.: A Photoelastic Study of Stresses in Gear Tooth Fillets, University of Illinois, Engineering Experimental Station Bulletin 335, 1942.

31. McIntire, W., Malott, R.; "Advancement of Spur Gear Design Technology," USAAVLABS Technical Report 66-85, U.S. Army Aviation Materiel Laboratories, Ft. Eustis, Virginia, 1966.

32. Savage, M., Radil, K. C., Lewicki, D. G., and Coy, J. J., "Computational Life and Reliability Modeling for Turboprop Transmissions," AIAA Jour. of Propulsion and Power, 5, 5, March - April 1996, pp. 610-614. 

